\title{
Immune defenses of healthy, bleached and diseased Montastraea faveolata during a natural bleaching event
}

\author{
Laura D. Mydlarz ${ }^{1, *}$, Courtney S. Couch ${ }^{2}$, Ernesto Weil ${ }^{3}$, Garriet Smith ${ }^{4}$, \\ C. Drew Harvell ${ }^{2}$ \\ ${ }^{1}$ Department of Biology, University of Texas at Arlington, Arlington, Texas 76019, USA \\ ${ }^{2}$ Department of Ecology and Evolutionary Biology, Corson Hall, Cornell University, Ithaca, New York 33431, USA \\ ${ }^{3}$ Department of Marine Sciences, University of Puerto Rico, PO Box 908, Lajas 00667, Puerto Rico \\ ${ }^{4}$ Department of Biology and Geology, University of South Carolina Aiken, 471 University Parkway, Aiken, \\ South Carolina 29801, USA
}

\begin{abstract}
One prominent hypothesis regarding climate change and scleractinian corals is that thermal stress compromises immune competence. To test this hypothesis we tracked how the immune defenses of bleached, apparently healthy and yellow band disease (YBD) diseased Montastraea faveolata colonies varied with natural thermal stress in southwestern Puerto Rico. Colonies were monitored for 21 mo from the peak of the bleaching event in October 2005 to August 2007. Since sea surface temperature was significantly higher in summer and fall 2005 than 2006, year of collection was used as a proxy for temperature stress, and colony fragments collected in 2005 were compared with those collected in 2006. Mortality rate was high (43\% overall) and all colonies (except one) either died or became infected with YBD by August 2007. YBD-infected tissue did not bleach (i.e. expel zooxanthellae) during the 2005 bleaching event, even when healthy tissue of these colonies bleached. Immune activity was assayed by measuring prophenoloxidase (PPO), peroxidase (POX), lysozyme-like (LYS) and antibacterial (AB) activity. Immune activity was variable between all coral samples, but there was a significant elevation of PPO activity in bleached colonies collected in 2005 relative to apparently healthy and YBD-diseased corals in 2006. In YBD-diseased colonies, LYS and $\mathrm{AB}$ activity were elevated in both healthy and infected tissue, indicating a systemic response; activity levels in these colonies were higher compared to those that appeared healthy. In both these immune parameters, there was a trend for suppression of activity in corals that were bleached in 2005. These data, while complicated by between-genet variability, illustrate the complex interaction between disease and temperature stress on immune function.
\end{abstract}

KEY WORDS: Coral bleaching $\cdot$ Montastraea faveolata $\cdot$ Yellow band disease $\cdot$ Prophenoloxidase Peroxidase $\cdot$ Antibacterial activity

\section{INTRODUCTION}

The synergistic effects of temperature stress and disease are taking their toll on coral health, with rapid mortality of massive reef-building corals such as Caribbean Montastraea spp. (Foley et al. 2005, Miller et al. 2006, Edmunds \& Elahi 2007). The recent decline of this genus has, however, been primarily due to yellow band disease (YBD), which has steadily increased in prevalence over the past 10 yr (Bruckner \& Bruckner 2006, Cróquer \& Weil 2009, Harvell et al. 2009). YBD is caused by a consortium of Vibrio species, which are believed to cause degradation of zooxanthellar cellular integrity in situ resulting in lesion development (Cervino et al. 2004a,b, 2008). The disease manifests as one or more focal, multifocal and/or irregular lesions with linear margins of yellow tissue bordering healthy tissue (Fig. 1) that progress at a rate of 0.6 to $3.5 \mathrm{~cm}^{2}$ 

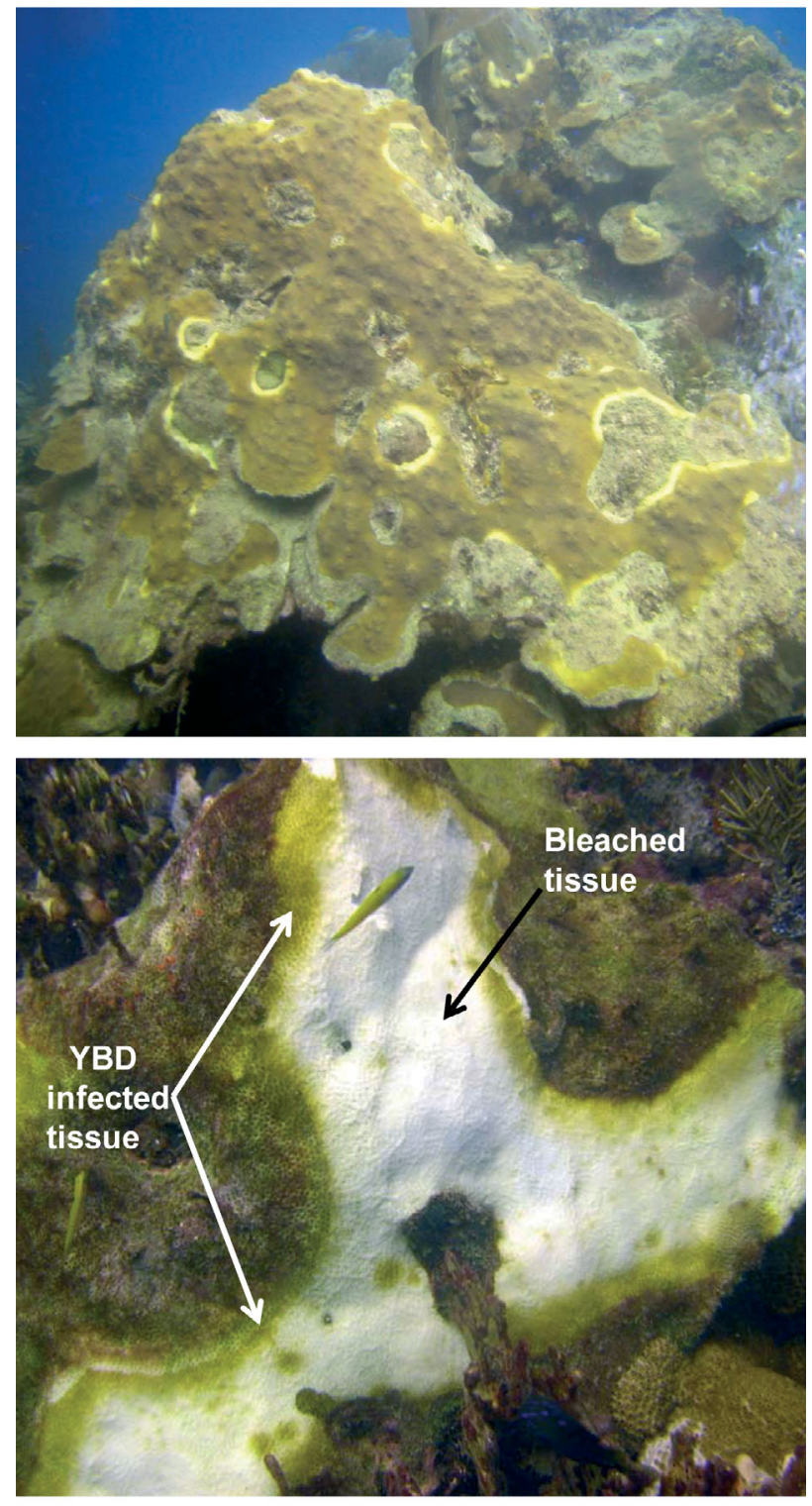

Fig. 1. Montastraea faveolata. Sampled M. faveolata colonies with yellow band disease (YBD). (A) Large colony with multiple YBD lesions. (B) Bleached colony with YBD. Note bleached tissue adjacent to YBD-infected tissue with substantial dead tissue

mo $^{-1}$ (Cervino et al. 2001, 2004b, Bruckner \& Bruckner 2006). Accelerated tissue loss and increased YBD prevalence have also been documented concurrent with elevated sea surface temperatures during summer months (Cervino et al. 2001, 2004b, Harvell et al. 2009). During the summer of 2005, sea surface temperatures rose $1^{\circ} \mathrm{C}$ above the maximum monthly mean for a continuous 14 wk period in several locations in the Caribbean (NOAA Coral Reef Watch 2007). Average sea surface temperatures from June to October 2005 were significantly higher than preceding years and the following June through October 2006 average (Clark et al. 2009). This resulted in widespread bleaching and mortality across the Caribbean with the epicenter in the US Virgin Islands and Puerto Rico, with some inshore reefs experiencing $90 \%$ bleaching (Oxenford et al. 2007). Furthermore, this event appeared to trigger outbreaks of white plague, white pox and YBD in the months that followed (Miller et al. 2006, Muller et al. 2008). However, the mechanisms by which temperature facilitates the spread of diseases, including YBD, and influences factors involved in coral resistance to diseases remain cryptic.

Corals respond to infection with a suite of innate immune defenses that are both cellular and humoral in nature. Several of these immune mechanisms have been well studied in the sea fan Gorgonia ventalina and other gorgonians (i.e. Meszaros \& Bigger 1999, Olano \& Bigger 2000, Petes et al. 2003, Mullen et al. 2004, Dishaw et al. 2005, Ellner et al. 2007, Douglas et al. 2007, Mydlarz \& Harvell 2007, Couch et al. 2008, Mydlarz et al. 2008) as well as scleractinian corals (i.e. Koh 1997, Miller et al. 2007, Gochfeld \& Aeby 2008, Kvennefors et al. 2008, Palmer et al. 2008, 2009). Recently, gene expression studies using complementary DNA (CDNA) microarrays have identified genes involved in stress pathways, namely temperature stress, in several scleractinian coral species (Edge et al. 2005, 2008, Desalvo et al. 2008, Schwartz et al. 2008). These molecular studies, combined with protein biomarker and cellular diagnostics to identify biochemical and cellular responses typically involved in stress and xenobiotic responses in corals (Downs et al. 2000, 2002, 2005, Ramos \& García 2007), have greatly advanced our understanding of coral stress responses. Since innate immunity and general stress pathways are likely intertwined, these studies have set the stage for further studies examining immune function during environmental stress (Mydlarz et al. 2008, Weis 2008).

Invertebrate innate immunity comprises several key cellular and protein components that play important roles in disease resistance. Prophenoloxidase (PPO) is an integral part of invertebrate immunity and is responsible for the production of melanin (Söderhäll et al. 1996, Söderhäll \& Cerenius 1998). The PPO pathway is also involved in wound healing, parasite and pathogen resistance and general coordination of immune responses (Nappi \& Christensen 2005, Mydlarz et al. 2006). PPO is the precursor to the active protein phenoloxidase, which is activated by release of proteases during the initial infection. Elevated PPO activity has been observed in fungus infected tissue of the sea fan Gorgonia ventalina (Mydlarz et al. 2008) as well as in abnormally pigmented tissue of the scleractinian coral Acropora millepora (Palmer et al. 2008). The super-family of peroxidase (POX) enzymes contains many isoforms that are in- 
volved in a variety of defense-related roles and oxygen scavenging (Hawkridge et al. 2000, Galloway \& Depledge 2001). In gorgonians, POX activity was detected in amoebocytes undergoing phagocytosis (Olano \& Bigger 2000) and was elevated in the initial hostpathogen responses in the sea fan coral (Mydlarz \& Harvell 2007). Another important aspect of innate immunity includes antibacterial proteins and peptides. Bacteriolytic or lysozyme-like (LYS) activity facilitated by a small lysozyme-like protein is commonly grouped with antibacterial peptides due to its small size and its ability to hydrolyze the $\beta-1,4$ glycosidic bond of peptidoglycans in bacterial cell walls (Bachali et al. 2002). LYS activity is an important antibacterial defense of several marine invertebrates, such as molluscs, crustaceans and echinoderms (Ordas et al. 2000, Bachali et al. 2002, Nappi \& Christensen 2005, Monari et al. 2007), and has recently been documented in sea fans (Couch et al. 2008). In addition, corals also produce bactericidal compounds and small peptides, which inhibit bacterial growth to a variety of pathogenic and non-pathogenic bacteria in vitro (Kim 1994, Koh 1997, Geffen \& Rosenberg 2005, Gochfeld \& Aeby 2008).

The role of temperature on host immunocompetence can be highly variable across species (Mydlarz et al. 2006) and has been shown to both stimulate and suppress elements of the innate immune system. For example, a heightened state of immunity as measured by increased circulating immune cells was observed in insects (Thomas \& Blanford 2003), crustaceans (Truscott \& White 1990, Cheng \& Chen 2001) and sea fan corals (Mydlarz et al. 2008) exposed to elevated temperatures. Elevated temperature has also been shown to increase phagocytic activity in sea cucumbers (Wang et al. 2008) and LYS activity in clam haemocytes (Monari et al. 2007). In contrast, suppressed PPO activity was detected in temperature-stressed brown shrimp (Vargas-Albores et al. 1998). The effects of temperature stress on immunity are especially confounded in corals that harbor photosynthetic symbionts and as such are susceptible to the damaging effects of photosynthetically produced reactive oxygen (Lesser 1996, 1997 , 2006, Tchernov et al. 2004, Weis 2008). This is further complicated by the fact that reactive oxygen is also a necessary immune defense and acts as a direct antimicrobial in phagocytosis and mediates several signaling cascades, such as PPO and programmed cell death (Nappi \& Christensen 2005, Lesser 2006). Therefore, the potential for chloroplast- and mitochondrialderived reactive oxygen to disrupt coral immune pathways is high, but not yet characterized. Due to the positive correlation between coral disease and thermal stress (Miller et al. 2006, Bruno et al. 2007, Harvell et al. 2009), we hypothesize that temperature stress results in an immune compromised state.
In the present study, we employed several innate immune assays commonly used in marine invertebrates to determine the immune function of bleached, apparently healthy (no visible signs of bleaching or disease) and YBD-diseased Montastraea faveolata colonies. Owing to the significant differences in monthly temperatures and accumulated heat index between 2005 and 2006 (NOAA Coral Reef Watch 2007, Wilkinson \& Souter 2008, Clark et al. 2009) we used collections during these years as a proxy for natural temperature stress. We predicted that bleached $M$. faveolata tissue collected during the 2005 bleaching event would have suppressed levels of immune activity compared to colonies that appeared healthy. We also predicted that during the 2005 bleaching event, YBD-diseased colonies would be immune-suppressed compared to apparently healthy colonies as well as compared to YBDdiseased colonies collected in 2006.

\section{MATERIALS AND METHODS}

Coral monitoring and collection. Ten bleached and 11 YBD-diseased Montastraea faveolata colonies were tagged and monitored from October 2005 to July 2007 on Turrumote Reef, La Parguera, Puerto Rico. Turrumote $\left(17^{\circ} 56.097^{\prime} \mathrm{N}, 67^{\circ} 01.130^{\prime} \mathrm{W}\right)$ is an exposed mid-shelf fringing reef located $2 \mathrm{~km}$ from shore. The reef runs east to west parallel to the shore line and has a shallow platform extending eastward and southward with a depth range between 0.5 and $4 \mathrm{~m}$. The drop-off is structurally complex and is mainly formed and dominated by large colonies of $M$. faveolata, $M$. annularis, M. franksi, M. cavernosa, Siderastrea siderea, Diploria strigosa, D. labyrinthiformis and Colpophyllia natans. The reef ends in a calcareous sandy bottom at 18 to $20 \mathrm{~m}$. A Hobo-pro temperature probe was placed at $15 \mathrm{~m}$ and temperature was recorded hourly. Hourly temperatures were averaged to obtain daily temperatures.

Colonies were tagged and photographed with numbered aluminum tags pinned with a nail to a dead area of the colony. The status of each colony was documented (and photographed) every $15 \mathrm{~d}$ for the first 2 mo, then every month for the next 7 mo and every 2 to 3 mo thereafter. Any changes in coloration, tissue mortality and new infections were noted. Apparently healthy colonies (no visible signs of bleaching or disease) were not monitored in the present study. Fragments from the 10 tagged bleached and 11 YBDdiseased colonies along with 10 untagged, randomly selected apparently healthy colonies were collected during October 2005 using a hammer and chisel. Colonies that appeared bleached in October 2005 were also collected in May 2006 when they had 
regained full pigmentation. Tissue from these recovered colonies was not collected in October 2006 because all but one colony became infected with YBD. The 11 YBD colonies were also collected in 2006 as they were still infected. In YBD-diseased colonies, one fragment (max. size $=25 \mathrm{~cm}^{2}$ ) was collected from the infected yellowed tissue, as well as an uninfected healthy tissue fragment from the same colony $(>20 \mathrm{~cm}$ away). One fragment each of similar size was collected from the center (away from the edges) of bleached colonies (white in appearance) and apparently healthy colonies. Fragments were placed in separate bags in a cooler filled with fresh seawater, taken to shore, immediately frozen in liquid nitrogen and shipped on dry ice to Cornell University. Samples were stored at $-80^{\circ} \mathrm{C}$ until extraction.

Extract preparation. Coral tissue was removed from the skeleton using a Badger ${ }^{\mathrm{TM}}$ airbrush with $0.1 \mathrm{M}$ phosphate buffer, $\mathrm{pH} 7.8$, with $2 \mathrm{mM} 2$-mercaptoethanol (Sigma-Aldrich). The tissue slurry was homogenized for $30 \mathrm{~s}$ with a hand-held tissue homogenizer and extracted for $45 \mathrm{~min}$ on ice. The volume of extract to the nearest $\mathrm{ml}$ was recorded and typically ranged from 6 to $15 \mathrm{ml}$. One $\mathrm{ml}$ of extract was removed for zooxanthellae cell counts; the remaining extract was frozen in liquid nitrogen and immediately lyophilized. After lyophilization, the powder was resuspended in pure molecular grade water (Sigma). To maintain consistent protein concentrations for all samples, $1 \mathrm{ml}$ water was added for every $5 \mathrm{ml}$ of extract. Upon resuspension of the extract, glass beads were added and the extract was vortexed for three $30 \mathrm{~s}$ periods to further disrupt the cells. The homogenate was extracted again on ice for $45 \mathrm{~min}$, transferred to a microcentrifuge tube and centrifuged at $14000 \times g$ for $5 \mathrm{~min}$ to remove cellular debris. The protein concentration of each extract was determined using the Bio-Rad DC Protein Assay Kit with a BSA standard. Extracts were stored at $-80^{\circ} \mathrm{C}$ between assays.

Zooxanthellae cell counts. The $1 \mathrm{ml}$ aliquot of unlyophilized tissue slurry was centrifuged at $10000 \times g$ for $10 \mathrm{~min}$ to pellet algal cells. The algal cells were washed twice with artificial seawater and resuspended in $200 \mu \mathrm{l}$ of $5 \%$ zinc buffered formalin (Z-fix ${ }^{\mathrm{TM}}$, Anatech Ltd., Battle Creek, MI, USA) in seawater. Zooxanthellae cells were counted using a hemocytometer and cells $\mathrm{ml}^{-1}$ calculated. To determine the total cell count per coral fragment, cells $\mathrm{ml}^{-1}$ was multiplied by the total volume of extract produced after airbrushing. The total cell count per coral fragment was normalized for surface area generating a standard curve of the weight and surface area of aluminum foil following methods described by Marsh (1970).

Enzymatic activity assays. All colorimetric measurements were calculated using a Synergy HT multidetection microplate reader with KC4 software (Biotek
Instruments). All assays were run in duplicate or triplicate on separate 96-well plates. Assays were run immediately after extraction (October 2005, May and October 2006) and then all samples were rerun in November 2006 to gather data presented here. There were no distinguishable changes in protein activity after storing the extracts at $-80^{\circ} \mathrm{C}$ for 1 yr. Boiled extracts were used as a negative control in all enzyme assays. In all cases activity was strongly diminished or completely inhibited (data not shown).

To measure POX activity, $10 \mu$ l of the crude protein extract were diluted with $40 \mu \mathrm{l}$ of $0.01 \mathrm{M}$ phosphate buffer, pH 6.0, and added to $50 \mu \mathrm{l}$ of $25 \mathrm{mM}$ guaiacol (Sigma-Aldrich) in $0.01 \mathrm{M}$ phosphate buffer, pH 6.0, in a 96-well plate (guaiacol final concentration of $10.8 \mathrm{mM}$ ). The reaction was initiated with the addition of $10 \mu \mathrm{l}$ of $20 \mathrm{mM}$ hydrogen peroxide (Sigma-Aldrich) (1.7 mM final concentration) prepared in $0.01 \mathrm{M}$ phosphate buffer, $\mathrm{pH} 6.0$, and optical density was measured over $15 \mathrm{~min}$ at $470 \mathrm{~nm}$. POX activity was represented as the change in absorbance at $470 \mathrm{~nm} \mathrm{~min}^{-1}$ and normalized among samples to mg protein (Mydlarz and Harvell 2007).

PPO activity was measured by adding $20 \mu \mathrm{l}$ of the extract to $130 \mu \mathrm{l}$ of $10 \mathrm{mM}$ stock of dopamine to measure the oxidation of dopamine (Sigma-Aldrich) to the colored oxidative product ( $7.5 \%$ final concentration). The reaction was initiated by the addition of $20 \mu \mathrm{l}$ of $1 \%$ sodium dodecyl sulphate and the absorbance monitored at $490 \mathrm{~nm}$ for $80 \mathrm{~min}$. Data are presented as change in absorbance (final - initial) per mg protein (Mydlarz et al. 2008).

LYS activity was measured by following a decrease in absorbance at $425 \mathrm{~nm}$ of freeze-dried Micrococcus luteus (Sigma-Aldrich) suspensions. Twenty $\mu \mathrm{l}$ of extract were added to $100 \mu \mathrm{l}$ of a $0.3 \%$ M. luteus suspension in $10 \mathrm{mM}$ phosphate buffer, $\mathrm{pH}$ 7.4. The reaction was incubated for $18 \mathrm{~h}$ at room temperature. Data are presented as proportion of M. luteus lysed compared to $M$. luteus suspensions with buffer alone divided by mg protein (Couch et al. 2008).

Antimicrobial assays. The antibacterial activity of the extracts was measured by comparing the inhibitory effects of the extracts on the bacterial growth rate of a Vibrio spp. isolated from the surface mucopolysaccharide layer of diseased Porites attenuata from reefs near Silman University Marine Laboratory, Dumaguette City, Philippines. Two volumes (10 and $100 \mu \mathrm{l})$ of each sample were spread onto glycerol artificial seawater (GASW) agar plates, in duplicate. Plates were incubated at $28^{\circ} \mathrm{C}$ for 24 to $72 \mathrm{~h}$. Resulting bacterial colonies were isolated based on colony morphology, as well as cellular size, shape, motility and capsule production. The bacterial isolate used in the present study was typed as Vibrio based on cell structure (phase- 
contrast and electron microscopy), colony morphology (pigmentation, elevation, size and margin type), growth test using acid production on thiosulfate citrate bile sucrose agar (TCBS), fatty acid analysis (FAME), carbon source utilization patterns (Biolog plates, Biolog) and sequencing of the 16S rRNA gene. GenBank BLAST searches of the 16S rRNA gene sequences were performed to determine the percentage of isolate relatedness to known bacteria (Altschul et al. 1997) (data not shown). The isolate was stored at $-80^{\circ} \mathrm{C}$ in cryovials containing $30 \%$ glycerol and $70 \%$ GASW medium.

An aliquot of the pure freezer stock was streaked on TCBS and incubated at $26^{\circ} \mathrm{C}$ for $24 \mathrm{~h}$. A single, distinct colony was removed, put into sterilized marine broth, and incubated again in a shaker at $26^{\circ} \mathrm{C}$ for $24 \mathrm{~h}$. To standardize the bacterial cell density in this assay, the culture was adjusted to an optical density of 0.2 at $600 \mathrm{~nm}$, which corresponded to approximately $5 \times$ $10^{7}$ cells ml ${ }^{-1}$ (S. Merkel pers. comm.). A dose response of Montastraea faveolata extract was performed to determine the necessary concentration to obtain 50 to $70 \%$ inhibition. Three $\mathrm{mg} \mathrm{ml}^{-1}$ of coral protein extract was deemed suitable and logarithmic growth occurred between 240 to $360 \mathrm{~min}$. Each extract was diluted to $3 \mathrm{mg} \mathrm{ml}^{-1}$ in $0.1 \mathrm{M}$ phosphate buffer, $\mathrm{pH}$ 7.8. In a 96well microtiter plate, $10 \mu \mathrm{l}$ of each extract were added to $105 \mu \mathrm{l}$ of marine broth and $15 \mu \mathrm{l}$ of the bacteria culture. Positive controls using $0.05 \mathrm{mg} \mathrm{ml}^{-1}$ of tetracycline and negative or vehicle controls using $0.1 \mathrm{M}$ phosphate buffer, $\mathrm{pH} 7.8$, were included on each plate. To calculate the percent inhibition of extracts, the number of generations was determined for each sample with the following equation: $3.3 \times \log \left(\mathrm{Abs}_{\text {final }} /\right.$ $\left.\mathrm{Abs}_{\text {initial }}\right)$. Then the number of generations was divided by the number of hours of logarithmic growth to produce the growth rate. Percent inhibition was determined using the following equation:

$$
I=(B C-B E) / B C \times 100
$$

where $I$ is percent inhibition, $B C$ is mean growth rate of bacteria control and $B E$ is mean growth rate of bacteria with extract (Couch et al. 2008).

Statistical analyses. Each immune and physiological parameter was averaged for each year of collection (2005 and 2006) and colony condition (bleached, apparently healthy, YBD healthy and infected tissue). Data were tested for normality and homoscedasticity (Shapiro-Wilks and Levene's test, respectively) prior to performing statistical analyses. Nonparametric data were power transformed using the Box-Cox Y method to meet parametric criteria of normality and equal variances. Immune activity and zooxanthellae density was compared across year and colony condition using a 2way multivariate ANOVA (MANOVA). The data were further evaluated using a univariate ANOVA and Tukey-Kramer post hoc tests for each immune parameter and zooxanthellae density. A semi-log model was used to determine the relationship between PPO, LYS and zooxanthellae density of bleached and apparently healthy colonies. Daily mean water temperatures $\left({ }^{\circ} \mathrm{C}\right)$ for the period between June and October 2005 and June and October 2006 were compared using a Student's $t$-test. All statistical analyses were performed on JMP Statistical Discovery Software version 6.0.3. (SAS Institute).

\section{RESULTS}

\section{Survey data and colony condition}

Mean summer and fall water temperatures between 1 June and 31 October were significantly higher in 2005 than 2006 (2005: $29.88 \pm 0.04^{\circ} \mathrm{C}_{i}$ 2006: 29.41土 $0.04^{\circ} \mathrm{C}$; $t$-test, $\left.\mathrm{p}<0.0001\right)$. In 2005 , there were 60 days between June and October that exceeded the bleaching threshold of $30.0^{\circ} \mathrm{C}$ (Manzello et al. 2007), including 4 days in September that were over $31.0^{\circ} \mathrm{C}$. In 2006 , only 17 days exceeded $30.0^{\circ} \mathrm{C}$ and none were over $31.0^{\circ} \mathrm{C}$. The colony condition and percent mortality of YBD-diseased and bleached colonies from October 2005 to July 2007 are presented in Table 1. Of the 2005 bleached colonies, all recovered their zooxanthellae and full pigmentation by May 2006 (Table 1), but $80 \%$ became infected with YBD by August 2006 and $90 \%$ by October 2006. None of the colonies originally infected with YBD during the 2005 bleaching event recovered, and 2 of these colonies also showed white plague signs in the following months. By July 2007, 5 of these 21 colonies remained alive but experienced $>35 \%$ partial mortality. Therefore, out of 21 tagged colonies that suffered from YBD or bleaching during October of 2005, only one remained healthy and otherwise unaffected by disease.

\section{Zooxanthellae cell counts}

Bleached colonies had significantly fewer zooxanthellae than healthy and diseased colonies, confirming that these colonies were indeed bleached (Fig. 2A, Table 2). Of the 11 YBD-diseased colonies we sampled in 2005, 5 were bleached in tissue not infected with YBD (i.e. Fig. 1B), but the mean zooxanthellae density from YBD-infected tissue did not vary significantly in healthy tissue from the same colonies or between years. Zooxanthellae isolated from YBD-infected tissue had less pigmentation than those from healthy areas (data not shown). 
Table 1. Montastraea faveolata. Survey data of the bleached and yellow band diseased (YBD) colonies sampled in 2005, 2006 and 2007. Note that healthy corals sampled in the present study were not surveyed. Estimates of partial mortality were determined based on field observations and colony photographs. Rec.: recovered; Part. rec.: partially recovered; WP: white plague; nd: no data

\begin{tabular}{|c|c|c|c|c|c|c|c|c|c|}
\hline \multirow{2}{*}{$\begin{array}{l}\text { Colony } \\
\text { ID }\end{array}$} & \multirow{2}{*}{$\begin{array}{l}\text { Oct } 2005 \\
\text { Colony } \\
\text { condition }\end{array}$} & \multicolumn{2}{|c|}{ May 2006} & \multicolumn{2}{|c|}{ Aug 2006} & \multicolumn{2}{|c|}{ Oct 2006} & \multicolumn{2}{|c|}{ Jul 2007} \\
\hline & & $\begin{array}{l}\text { Colony } \\
\text { condition }\end{array}$ & $\begin{array}{c}\% \\
\text { mortality }\end{array}$ & $\begin{array}{l}\text { Colony } \\
\text { condition }\end{array}$ & $\begin{array}{c}\% \\
\text { mortality }\end{array}$ & $\begin{array}{c}\text { Colony } \\
\text { condition }\end{array}$ & $\begin{array}{c}\% \\
\text { mortality }\end{array}$ & $\begin{array}{c}\text { Colony } \\
\text { condition }\end{array}$ & $\begin{array}{c}\% \\
\text { mortality }\end{array}$ \\
\hline 401 & Bleached & Rec. & 15 & YBD & 15 & YBD & 30 & YBD & 50 \\
\hline 402 & Bleached & Rec. + YBD & 35 & YBD & 40 & YBD & 50 & YBD & 75 \\
\hline 403 & Bleached & Rec. & 15 & YBD & 15 & YBD & 60 & Dead & 100 \\
\hline 404 & Bleached & Rec. & 40 & YBD & 40 & YBD & 70 & Dead & 100 \\
\hline 405 & Bleached & Rec. & 10 & YBD & 30 & YBD & 50 & Dead & 100 \\
\hline 406 & Bleached & Rec. & 10 & YBD & 10 & YBD & 50 & YBD & 80 \\
\hline 407 & Bleached & Part. rec. & 15 & Healthy & 15 & YBD & 35 & YBD & 70 \\
\hline 408 & Bleached & Part. rec. & 15 & YBD & 15 & YBD & 40 & YBD & 60 \\
\hline 409 & Bleached & Rec. & 20 & YBD & 20 & YBD & 30 & YBD & 45 \\
\hline 410 & Bleached & Rec. & 0 & Healthy & 0 & Healthy & 0 & Healthy & 0 \\
\hline 324 & YBD & YBD & 45 & nd & nd & Dead & 100 & Dead & 100 \\
\hline 415 & YBD & YBD & 30 & nd & nd & Dead & 100 & Dead & 100 \\
\hline 417 & YBD & $\mathrm{YBD}+\mathrm{WP}$ & 60 & YBD & 90 & Dead & 100 & Dead & 100 \\
\hline 549 & YBD & YBD & 10 & nd & nd & YBD & 25 & YBD & 40 \\
\hline 557 & YBD & YBD & 5 & nd & nd & YBD & 15 & YBD & 35 \\
\hline 695 & YBD & $\mathrm{YBD}+\mathrm{WP}$ & 50 & YBD & 70 & Dead & 100 & Dead & 100 \\
\hline 412 & YBD + Bleached & YBD & 25 & YBD & 40 & YBD & 60 & Dead & 100 \\
\hline 413 & YBD + Bleached & YBD & 15 & YBD & 25 & YBD & 40 & YBD & 50 \\
\hline 416 & YBD + Bleached & YBD & nd & YBD & 25 & YBD & 30 & YBD & 60 \\
\hline 418 & YBD + Bleached & YBD & 25 & YBD & 70 & Dead & 100 & Dead & 100 \\
\hline 543 & YBD + Bleached & YBD & nd & YBD & nd & YBD & 50 & YBD & 80 \\
\hline
\end{tabular}

\section{Immune protein activity}

All immune proteins and antimicrobial activity (PPO, POX, LYS, AB) varied significantly as a function of year of collection and condition (Table 2). PPO and LYS activity were the only responses that varied significantly for both colony condition and year of collection.

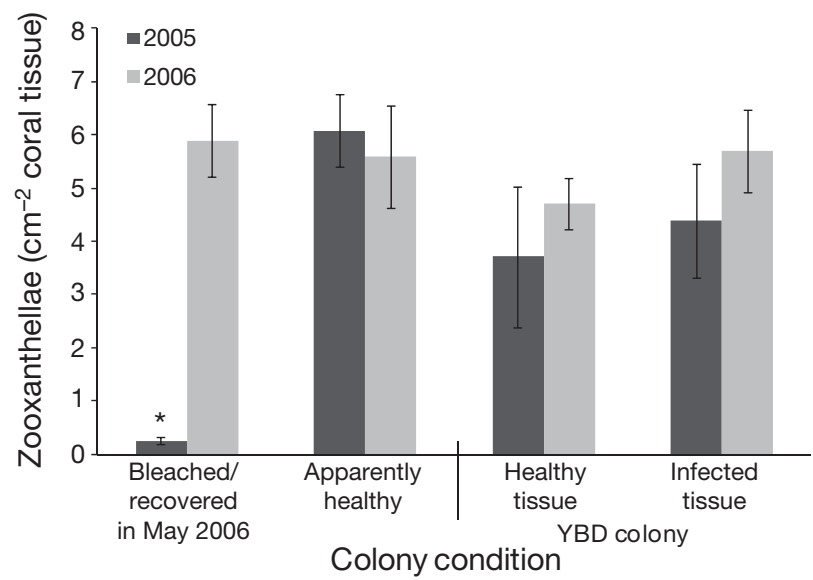

Fig. 2. Mean $( \pm \mathrm{SE})$ zooxanthellae density in corals during October 2005 (thermal anomaly) and October 2006 (from Table $1, \mathrm{n}=7$ to $11, F=3.6, \mathrm{p}=0.0022$ ). Bleached colonies were resampled in May 2006 upon recovery of full pigmentation. * Significant difference at $\mathrm{p}<0.05$
The variation in POX was driven by significant differences between 2005 and $2006(F=12.0$, df $=1, \mathrm{p}=$ 0.0009).

PPO activity was significantly higher in 2005 bleached colonies than in apparently healthy colonies collected in October 2006 (Fig. 3A). The recovered bleached colonies in May 2006 had intermediate PPO activity, whereas all apparently healthy and diseased colonies collected in 2006 had significantly less PPO activity $(F=33.5$, df $=1, \mathrm{p}<0.0001)$. There was a negative relationship between PPO and zooxanthellae density in bleached and apparently healthy colonies $\left(\mathrm{PPO}=-0.56 \log \left[\right.\right.$ zooxanthellae $\left.\mathrm{cm}^{-2}\right]+10.15, \mathrm{R}^{2}=$ $0.31, F=15.4, p=0.0004$ ) (Fig. 3B). POX activity was significantly higher in apparently healthy colonies collected in 2005 than those collected in 2006 (Fig. 4). Recovered bleached and diseased colonies in 2006 had POX levels comparable to apparently healthy corals.

LYS and $\mathrm{AB}$ activity showed parallel trends that were opposite those of PPO and POX (Figs. 5A \& 6). Bleached corals had the lowest levels of both LYS and $\mathrm{AB}$ activity (LYS, $F=4.2, \mathrm{df}=3, \mathrm{p}=0.0083 ; \mathrm{AB}, F=7.4$, $\mathrm{df}=3, \mathrm{p}=0.0002$ ) and subsequently there was a positive relationship between LYS activity and zooxanthellae density in bleached and apparently healthy corals $\left(\right.$ LYS $=0.82 \log \left[\right.$ zooxanthellae $\left.\mathrm{cm}^{-2}\right]-6.15, \mathrm{R}^{2}=0.15$, 
Table 2. Two-way MANOVA and univariate results examining the effects of year of collection (2005 and 2006), colony condition (bleached, apparently healthy and healthy and infected tissue from diseased colonies) and their interaction on immune protein activity and zooxanthellae density. Bold text indicates significance less than $\alpha=0.05$

\begin{tabular}{|c|c|c|c|c|c|c|c|c|c|c|c|c|}
\hline & \multicolumn{3}{|c|}{ Whole model } & \multicolumn{3}{|c|}{ Year (2005 vs. 2006) } & \multicolumn{3}{|c|}{ Colony condition } & \multicolumn{3}{|c|}{ Year $\times$ Colony condition } \\
\hline & $F$ & $\mathrm{df}$ & $\mathrm{p}$ & $F$ & $\mathrm{df}$ & $\mathrm{p}$ & $F$ & df & $\mathrm{p}$ & $F$ & $\mathrm{df}$ & $\mathrm{p}$ \\
\hline \multicolumn{13}{|l|}{ MANOVA } \\
\hline Wilk's Lamda & 3.4 & 35 & $<0.0001$ & 10.7 & 5 & $<0.0001$ & 3.83 & 15 & $<0.0001$ & 1.3 & 15 & 0.1919 \\
\hline$F$-test & 198.5 & 5 & $<0.0001$ & & & & & & & & & \\
\hline \multicolumn{13}{|l|}{ Univariate tests } \\
\hline Prophenoloxidase & 8.1 & 7 & $<0.0001$ & 33.5 & 1 & $<0.0001$ & 5.5 & 3 & 0.0019 & 1.0 & 3 & 0.3883 \\
\hline Peroxidase & 2.7 & 7 & 0.0162 & 12.0 & 1 & 0.0009 & 1.3 & 3 & 0.2926 & 1.7 & 3 & 0.1681 \\
\hline Lysozyme-like & 3.2 & 7 & 0.0052 & 8.7 & 1 & 0.0043 & 4.2 & 3 & 0.0083 & 0.6 & 3 & 0.6450 \\
\hline Antibacterial & 3.3 & 7 & 0.0038 & 0.3 & 1 & 0.6105 & 7.4 & 3 & 0.0002 & 0.4 & 3 & 0.7367 \\
\hline Zooxanthellae $\mathrm{cm}^{-2}$ & 3.6 & 7 & 0.0022 & 6.9 & 1 & 0.0106 & 2.6 & 3 & 0.0583 & 3.3 & 3 & 0.0244 \\
\hline
\end{tabular}

$F=6.4, \mathrm{p}=0.016$ ) (Fig. 5B). While not significant, LYS and $\mathrm{AB}$ appeared to be induced systemically, with higher activity in infected and healthy tissue from YBD colonies compared to colonies that were apparently healthy (Figs. 5A \& 6).
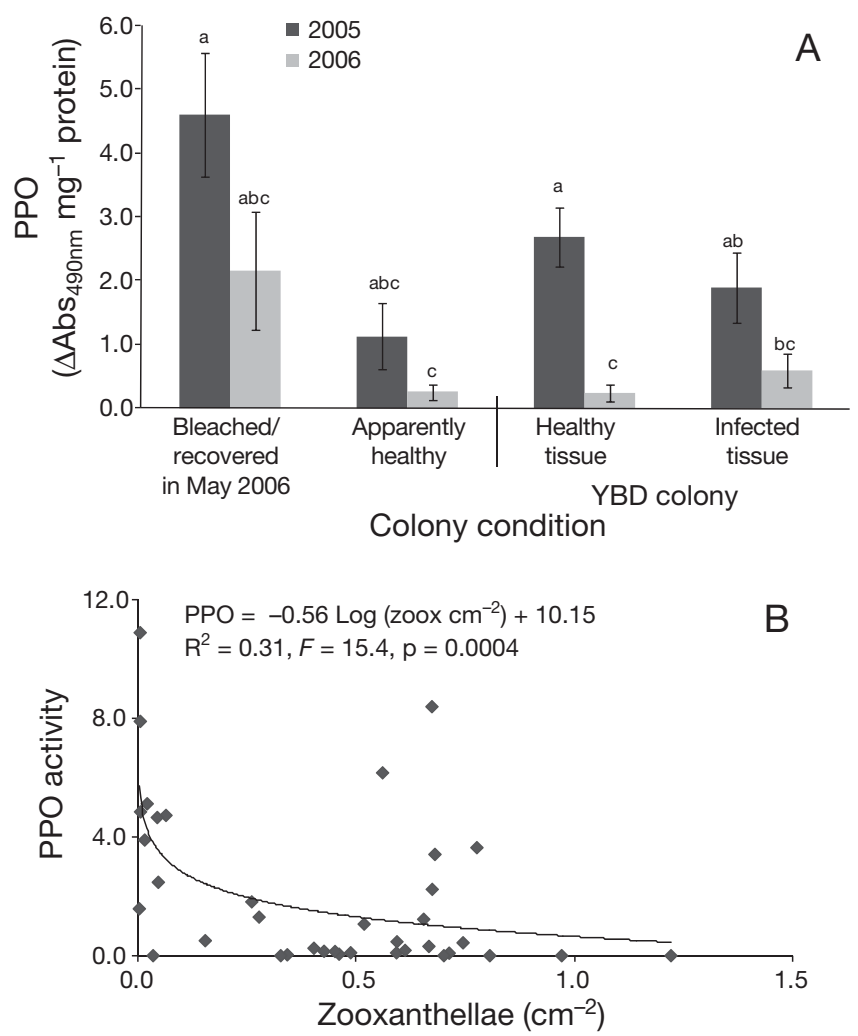

Fig. 3. (A) Mean $( \pm \mathrm{SE})$ prophenoloxidase (PPO) activity in October 2005 and 2006. Bleached colonies were resampled in May 2006 upon recovery of full pigmentation. (MANOVA, $F=$ 8.1, $\mathrm{p}<0.0001$, letters indicate significant difference at $\mathrm{p}<$ 0.05). (B) Negative relationship between zooxanthellae density and PPO in apparently healthy and bleached corals

\section{DISCUSSION}

Several key innate immune responses were measured in Montastraea faveolata infected with YBD during the warmest sea surface temperatures in over $100 \mathrm{yr}$. This is the first study to follow and sample the immune competence of healthy and diseased corals through a massive bleaching event which may have prompted outbreaks of white plague, white pox and YBD (Miller et al. 2006, Muller et al. 2008, E. Weil pers. obs.). Although many environmental conditions may lead to bleaching, temperature is widely accepted as one of the primary causes (Hoegh-Guldberg et al. 2007, Weis 2008). In 2005, Puerto Rican reefs experienced 12 to 14 consecutive weeks of elevated temperatures, while during the same period in 2006 the temperatures were lower and elevated for only 1 to 2 consecutive weeks, as recorded by our own temperature loggers and NOAA Coral Reef Watch (2007). Although we did not manipulate temperature in the present study, our data provides additional evidence

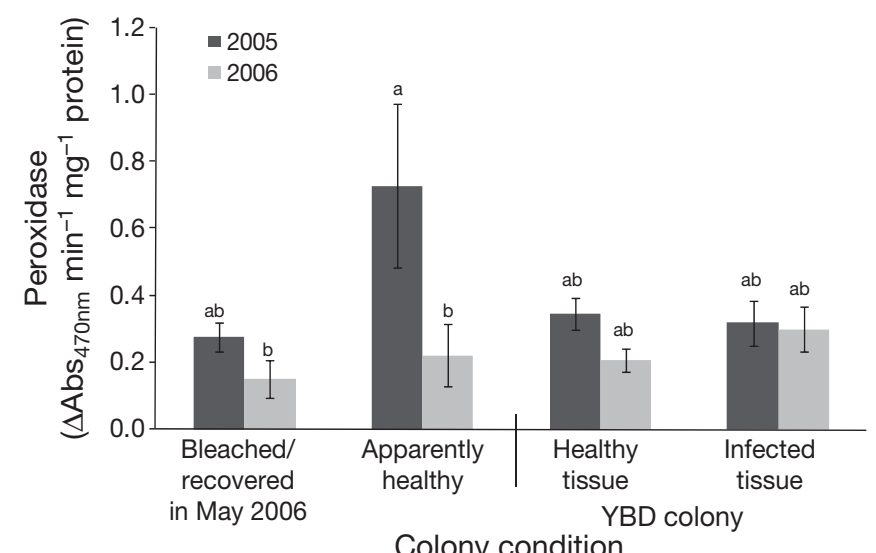

Colony condition

Fig. 4. Mean $( \pm$ SE) peroxidase activity in October 2005 and 2006. Bleached colonies were resampled in May 2006 upon recovery of full pigmentation (MANOVA, $F=2.7, \mathrm{p}=0.0162$, letters indicate significant difference at $\mathrm{p}<0.05$ ) 

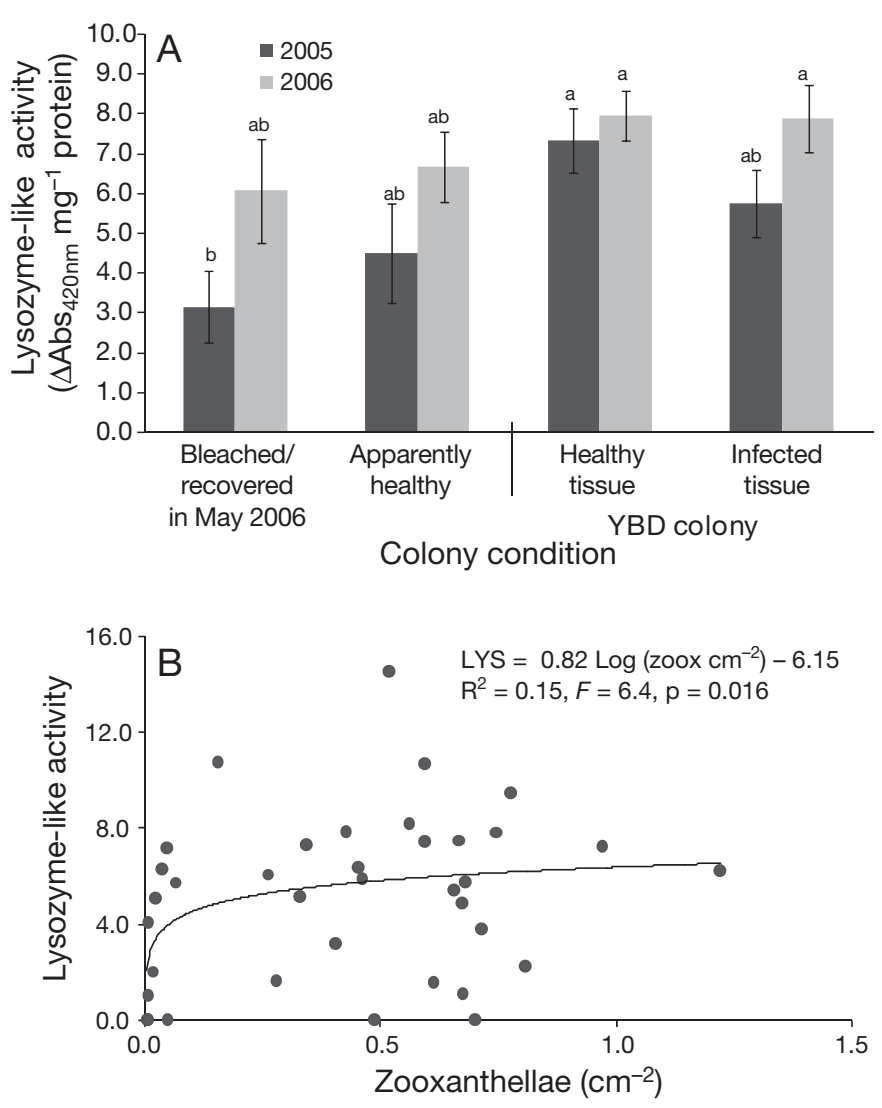

Fig. 5. (A) Mean ( \pm SE) lysozyme-like (LYS) activity in October 2005 and 2006. Bleached colonies were resampled in May 2006 upon recovery of full pigmentation (MANOVA, $F=3.2$, $\mathrm{p}=0.0052$, letters indicate significant difference at $\mathrm{p}<0.05$ ). (B) Negative relationship between zooxanthellae density and LYS activity in apparently healthy and bleached corals

that late summer temperatures varied significantly between 2005 and 2006 (Wilkinson \& Souter 2008, Clark et al. 2009), and that this thermal stress had significant deleterious effects on overall coral health, as evident by the mass bleaching, disease outbreaks and subsequent mortality.

Of the 21 bleached and YBD-diseased corals originally sampled, only one remained alive and not infected by disease in 2007 . The zooxanthellae counts confirm that bleached colonies expelled a majority of their symbionts in addition to the visible loss of photosynthetic pigments, while apparently healthy corals in 2005 retained both their pigmentation and zooxanthellae. Conversely, YBD-infected tissue did not expel zooxanthellae regardless of the presence of bleaching in the surrounding tissue. Zooxanthellae isolated from YBD-infected tissue were pale and misshapen as initially reported by Cervino et al. (2004a,b). Our data further supports the conclusion that zooxanthellae in YBD-infected tissue are impaired but not subsequently expelled as in bleached tissue (Cervino et al. 2004a,b).

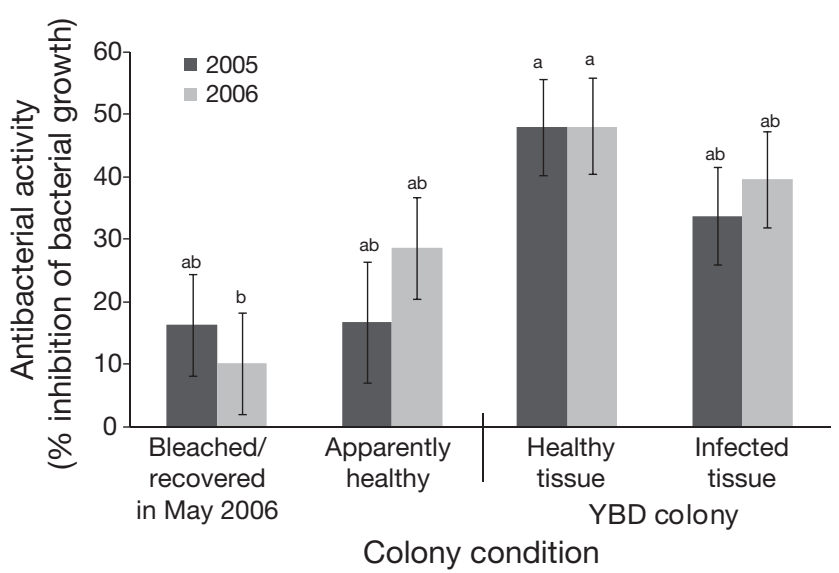

Fig. 6. Mean $( \pm$ SE) antibacterial activity in October 2005 and 2006. Bleached colonies were resampled in May 2006 upon recovery of full pigmentation (MANOVA, $F=3.3, p=0.0038$, letters indicate significant difference at $\mathrm{p}<0.05$ )

The levels of all immune and defense proteins measured in the present study were altered due to bleaching or YBD infection. Most noteworthy was the effect of the 2005 temperature stress on PPO activity. Although we predicted that bleached corals would have suppressed immune defenses, quantified by decreased activity of certain factors involved in disease resistance, we observed the opposite. The mechanisms underlying the increased PPO activity could range from temperature directly affecting enzymes or cofactors in the PPO cascade, or indirectly as a result of general stress responses. Alternatively we suggest 2 potential hypotheses as causes of elevated PPO during thermal stress: disruption of calcium stores and zooxanthellae-based suppression of immunity.

Using temperature-stressed and near-bleached samples of Montastraea faveolata, Desalvo et al. (2008) found that several genes that regulate calcium stores were down-regulated, suggesting an increase of intracellular calcium. Furthermore, previous studies on Acropora grandis found that high calcium levels were concomitant with bleaching (Fang et al. 1997). Several well-characterized invertebrate PPOs are also known to be dependent on calcium (Leonard et al. 1985, Gollas-Galván et al. 1997) and can be activated by exogenous calcium addition (Gollas-Galván et al. 1997). Therefore, the increase in PPO activity we detected in bleached $M$. faveolata could be an indirect result of calcium stimulation. Another, albeit more complex, hypothesis is that zooxanthellae block host immune responses in order to persist in the host tissue and cells as proposed by Weis et al. (2008). As a result, host immune function would increase during bleaching and expelling of the symbionts. Whichever upstream signaling accounts for this increase in PPO activity, there 
is evidence for a relationship between PPO levels and disease resistance in other invertebrate models (Nigam et al. 1997, Siva-Jothy 2000, Mucklow et al. 2004, Newton et al. 2004). However, in the present study, elevated PPO did not appear to confer disease resistance or may have been too transient to do so, as PPO activity decreased in subsequent collections and all but one colony became infected or died from YBD.

Although no significant effects of YBD infection on PPO activity were detected by the MANOVA analysis, the mean PPO activity in infected tissue was 2 times higher compared to healthy tissue from the same colony in 2006; in fact, all 12 colonies showed an induction of PPO in infected tissue. Due to the multivariate nature of our analyses and large between-colony variation, this individual response was concealed. When compared with a paired design, YBD-infected tissue was significantly different from healthy tissue collected from the same colony during 2006, but not in 2005 (paired $t$-test, healthy vs. infected tissue, 2006: $\mathrm{p}=0.037 ; 2005: \mathrm{p}=0.161)$. It is possible that the spike in PPO activity in temperature-stressed Montastraea faveolata may have masked or suppressed any disease-related induction. The magnitude of natural variability in $M$. faveolata PPO levels was attributed to actual between-genet variation and not the PPO assay, as within-assay sample replicates did not vary, which coincides with previous findings in other coral genera (Couch et al. 2008, Mydlarz et al. 2008, Palmer et al. 2008). At this time it is unclear whether this natural variability in PPO contributes to the variability in YBD severity observed between colonies (Harvell et al. 2009). Nevertheless, PPO up-regulation in response to infection is an important invertebrate pathway and is proving to be equally as important in corals, as is supported by recent reports of elevated levels of PPO in fungus-infected sea fan tissue (Mydlarz et al. 2008) and abnormally pigmented Acropora millipora (Palmer et al. 2008). Although in the same report (Palmer et al. 2008), Porites spp. did not show an equivalent induction of PPO in abnormally pigmented tissue, suggesting variability of this response among anthozoans.

POX activity was also highly dependent on year of collection rather than colony condition. POX was approximately 3 times higher in apparently healthy colonies in 2005 when compared to healthy colonies in 2006 and bleached colonies in 2005, indicating that although these corals appeared healthy, the effects of elevated temperature were occurring intracellularly. POX is well known for its ability to scavenge free radicals (Gamble et al. 1995), and the role of antioxidants during bleaching to mitigate the damage caused by photoinhibition has been investigated in both the symbiont and coral host (Lesser 1997, 1996, Lesser \& Farrell 2004). Downs et al. (2000) and Desalvo et al. (2008) also documented elevated antioxidant activity and gene up-regulation, respectively, in Montastraea faveolata experimentally exposed to high temperatures. In the present study, POX was only elevated in colonies that retained their zooxanthellae during the 2005 bleaching event, supporting the hypothesis that oxidative stress can be mitigated by expelling the symbiont (Lesser 1996, 1997). Since our assays did not distinguish between host and algal POX, it is possible that elevated levels resulted from a combination of the zooxanthellae undergoing oxidative stress and the host's attempts to protect itself against thermal damage. There was no change in POX activity in YBDinfected tissue, which is surprising as the disease seems to impair zooxanthellae and is believed to disrupt biochemical processes on thylakoid membranes during photosynthesis (Cervino et al. 2004a), which may cause an increase in reactive oxygen similar to thermal bleaching. Mydlarz \& Harvell (2007) measured a POX induction in sea fan corals exposed to a pathogen after $1 \mathrm{wk}$, indicating an early response to pathogen exposure; it is possible that in our sampling design we missed this early immune response to YBD pathogens.

The AB and LYS activity of coral extracts were the only immune parameters measured that followed the expected trend for suppression during temperature stress and were lower during the bleaching event or shortly thereafter. This is further corroborated by a positive correlation between LYS and zooxanthellae numbers. The source of the AB and bacteriolytic activity is unknown and may derive from the host, zooxanthellae or bacterial community within the surface mucosal layer and tissues. Bleaching has been shown to cause changes in coral microbial community structure as well as functional changes in allelopathic activity, resulting in reduced antibacterial activity (Ritchie 2006). Regardless of the source, temperature-induced modifications of these important allelopathic interactions may render the coral holobiont susceptible to exogenous or pathogenic bacteria that may otherwise be destroyed.

Overall, LYS and AB activity were highest in YBDdiseased colonies, both in healthy and infected tissues, indicating a systemic rather than localized response to infection. In insects, systemic responses include antimicrobial peptides, whereas localized responses involve cellular processes (Lemaitre \& Hoffmann 2007). The increase in bacteriolytic and bactericidal properties of diseased corals may also be a function of changes in the bacterial community composition that arise during infection (Ritchie \& Smith 1995, GilAgudelo et al. 2007). Furthermore, Pantos et al. (2003) found that there were systemic changes in bacterial communities on Montastraea annularis with even 
small white plague-like lesions. Thus changes in bacterial communities across an entire diseased colony could result in increased or decreased antibacterial activity, but without knowing the source of the compounds only associated patterns can be described.

While the present study provides evidence for immune compromise (LYS and AB) as well as immune stimulation (PPO) in Montastraea faveolata during the warmer-than-average fall of 2005 and the average temperature fall of 2006, 20 of 21 colonies surveyed died from YBD infection by the end of the study. Therefore, certain aspects of this disease, whether pathogen- or host-related, were accelerated by the above-average water temperatures and/or bleaching. This unusual period of warming may have left immune defenses exhausted, leading to unimpeded pathogen colonization of new $M$. faveolata colonies and faster spread of the disease into uninfected areas of diseased colonies. At this time, it is not possible to identify whether the increase in YBD prevalence was due to the suppression of certain immune factors, increased pathogen virulence, changes in the protective surface musosal layer, other extraneous factors or a combination of these elements. However, our results contribute to the understanding of how bleaching and temperature stress affect several immune components and illustrate the importance of monitoring several immune parameters independently in a large sample of bleached, apparently healthy and diseased corals. While these data did reveal evidence of compromised immunity in a scleractinian coral during climate stress, they also illustrate the complexity of the synergistic interaction between temperature and disease.

Acknowledgements. Funding for this project was provided by the National Science Foundation (NSF) grant OCE-0326705 in the NSF/National Institutes of Health Ecology of Infectious Diseases program, the National Geographic Creative and Research Explorer grant to C.D.H. and L.D.M., as well as Global Environment Facility (World Bank) Coral Reef Targeted Research Program support to C.D.H. and E.W. Additional funding and logistical support was provided by the NOAA Coral Reef Ecosystems Studies project and the Department of Marine Sciences, University of Puerto Rico, to E.W. We thank A. Cróquer and E. Irizarry for dive support during this project, S. Merkel for assistance with the development of the antibacterial assay used in this study and L. Raymundo for assistance with bacterial isolations.

\section{LITERATURE CITED}

Altschul SF, Madden TL, Schaffer A, Zhang J, Zhang Z, Miller W, Lipman DJ (1997) Gapped BLAST and PSI-BLAST: a new generation of protein database search programs. Nucleic Acids Res 25:3389-3402

Bachali S, Jager M, Hassanin A, Schoentgen F, Jolles P, FialaMedioni A, Deutsch JS (2002) Phylogenetic analysis of invertebrate lysozymes and the evolution of lysozyme function. J Mol Evol 54:652-664

Bruckner AW, Bruckner RJ (2006) Consequences of yellow band disease (YBD) on Montastraea annularis (species complex) populations on remote reefs off Mona Island, Puerto Rico. Dis Aquat Org 69:67-73

Bruno JF, Selig ER, Casey KS, Page CA and others (2007) Thermal stress and coral cover as drivers of coral disease outbreaks. PLoS Biol 5:e124, doi:10.1371/journal.pbio. 0050124

Cervino J, Goreau TJ, Nagelkerken I, Smith GW, Hayes R (2001) Yellow band and dark spot syndromes in Caribbean corals: distribution, rate of spread, cytology, and effects on abundance and division of zooxanthellae. In: Porter JW (ed) The ecology and etiology of newly emerging marine diseases. Developments in hydrobiology 159. Kluwer Academic Publishers, Dordrecht, p 53-63

Cervino JM, Hayes RL, Goreau TJ, Smith GW (2004a) Zooxanthellae regulation in yellow blotch/band and other coral diseases contrasted with temperature related bleaching: in situ destruction vs. expulsion. Symbiosis 37:63-85

Cervino JM, Hayes RL, Polson SW, Polson SC, Goreau TJ, Martinez RJ, Smith GW (2004b) Relationship of Vibrio species infection and elevated temperatures to yellow blotch/band disease in Caribbean corals. Appl Environ Microbiol 70:6855-6864

> Cervino JM, Thompson FL, Gomez-Gil B, Lorence EA and others (2008) The Vibrio core group induces yellow band disease in Caribbean and Indo-Pacific reef-building corals. J Appl Microbiol 105:1658-1671

Cheng W, Chen JC (2001) Effects of intrinsic and extrinsic factors on the haemocyte profile of the prawn, Macrobrachium rosenbergii. Fish Shellfish Immunol 11:53-63

Clark R, Jeffry C, Woody K, Hillis-Starr Z, Monaco M (2009) Spatial and temporal patterns of coral bleaching around Buck Island Reef national monument, St. Croix, U.S. Virgin Islands. Bull Mar Sci 84:167-182

> Couch CS, Mydlarz LD, Harvell CD, Douglas NL (2008) Variation in measures of immunocompetence of sea fan coral, Gorgonia ventalina, in the Florida Keys. Mar Biol 155: 281-292

Cróquer A, Weil E (2009) Spatial variability in distribution and prevalence of Caribbean scleractinian coral and octocoral diseases. II. Genera-level analysis. Dis Aquat Org 83: 209-222

> Desalvo MK, Voolstra CR, Sunagawa S, Schwarz JA and others (2008) Differential gene expression during thermal stress and bleaching in the Caribbean coral Montastraea faveolata. Mol Ecol 17:3952-3971

> Dishaw LJ, Smith SL, Bigger C (2005) Characterization of a C3-like cDNA in a coral: phylogenetic implications. Immunogenetics 57:535-548

Douglas NL, Mullen K, Talmage S, Harvell CD (2007) Exploring the role of chitinolytic enzymes in the sea fan coral Gorgonia ventalina. Mar Biol 150:1137-1144

> Downs CA, Mueller E, Phillips S, Fauth JE, Woodley CM (2000) A molecular biomarker system for assessing the health of coral (Montastraea faveolata) during heat stress. Mar Biotechnol 2:533-544

Downs CA, Fauth JE, Halas JC, Dustan P, Bemiss J, Woodley CM (2002) Oxidative stress and seasonal coral bleaching. Free Radic Biol Med 33:533-543

> Downs CA, Fauth JE, Robinson CE, Curry R and others (2005) Cellular diagnostics and coral health: declining coral health in the Florida Keys. Mar Pollut Bull 51:558-569

$>$ Edge SE, Morgan MB, Gleason DF, Snell TW (2005) Development of a coral cDNA array to examine gene expression 
profiles in Montastraea faveolata exposed to environmental stress. Mar Pollut Bull 51:507-523

Edge SE, Morgan MB, Terry W, Snell TW (2008) Temporal analysis of coral gene expression in a field population. J Exp Mar Biol Ecol 355:114-124

Edmunds PJ, Elahi R (2007) The demographics of a 15-year decline in cover of the Caribbean reef coral Montastraea annularis. Ecol Monogr 77:3-18

Ellner SP, Jone LE, Mydlarz LD, Harvell CD (2007) Withinhost disease ecology in the sea fan Gorgonia ventalina: modeling the spatial immunodynamics of a coralpathogen interaction. Am Nat 170:E143-E161

Fang LS, Huang SP, Lin KL (1997) High temperature induces the synthesis of heat-shock proteins and the elevation of intracellular calcium in the coral Acropora grandis. Coral Reefs 16:127-131

Foley JE, Sokolow SH, Girvetz E, Foley CW, Foley P (2005) Spatial epidemiology of Caribbean yellow band syndrome in Montastrea spp. coral in the eastern Yucatan, Mexico. Hydrobiologia 548:33-40

> Galloway TS, Depledge MH (2001) Immunotoxicology in invertebrates: measurement and ecotoxicological review. Ecotoxicology 10:5-23

Gamble SC, Goldfarb PS, Porte C, Livingstone DR (1995) Glutathione peroxidase and other antioxidant enzyme function in marine invertebrates (Mytilus edulis, Pecten maximus, Carcinus maenas and Asterias rubens). Mar Environ Res 39:191-195

> Geffen Y, Rosenberg E (2005) Stress-induced rapid release of antibacterials by scleractinian corals. Mar Biol 146: 931-935

> Gil-Agudelo DL, Fonseca DP, Weil E, Garzon-Ferreira J, Smith GW (2007) Bacterial communities associated with the mucopolysaccharide layers of three coral species affected and unaffected with dark spots disease. Can J Microbiol 53:465-471

> Gochfeld DJ, Aeby GS (2008) Antibacterial chemical defenses in Hawaiian corals provide possible protection from disease. Mar Ecol Prog Ser 362:119-128

- Gollas-Galván T, Hernandez-Lopez J, Vargas-Albores F (1997) Effect of calcium on the prophenoloxidase system activation of the brown shrimp (Penaeus californiensis, Holmes). Comp Biochem Physiol A 117:419-425

> Harvell D, Altizer S, Cattadori IM, Harrington L, Weil E (2009) Climate change and wildlife diseases: When does the host matter the most? Ecology 90:912-920

> Hawkridge JM, Pipe RK, Brown BE (2000) Localization of antioxidant enzymes in the cnidarians Anemonia viridis and Goniopora stokesi. Mar Biol 137:1-9

Hoegh-Guldberg O, Mumby PJ, Hooten AJ, Steneck RS and others (2007) Coral reefs under rapid climate change and ocean acidification. Science 318:1737-1742

Kim K (1994) Antimicrobial activity in gorgonian corals (Coelenterata, Octocorallia). Coral Reefs 13:75-80

Koh EGL (1997) Do scleractinian corals engage in chemical warfare against microbes? J Chem Ecol 23:379-398

Kvennefors ECE, Leggat W, Hoegh-Guldberg O, Degnan BM, Barnes AC (2008) An ancient and variable mannosebinding lectin from the coral Acropora millepora binds both pathogens and symbionts. Dev Comp Immunol 32: 1582-1592

- Lemaitre B, Hoffmann J (2007) The host defense of Drosophila melanogaster. Annu Rev Immunol 25:697-743

> Leonard C, Söderhäll K, Ratcliff NA (1985) Studies on prophenoloxidase and protease activity of Blaberus cranifer heamocytes. Insect Biochem 15:803-810

Lesser MP (1996) Elevated temperatures and ultraviolet radi- ation cause oxidative stress and inhibit photosynthesis in symbiotic dinoflagellates. Limnol Oceanogr 41:271-283

Lesser MP (1997) Oxidative stress causes coral bleaching during exposure to elevated temperatures. Coral Reefs 16: 187-192

Lesser MP (2006) Oxidative stress in marine environments: biochemistry and physiological ecology. Annu Rev Physiol 68:253-278

Lesser MP, Farrell JH (2004) Exposure to solar radiation increases damage to both host tissues and algal symbionts of corals during thermal stress. Coral Reefs 23:367-377

- Manzello DP, Berkelmans R, Hendee JC (2007) Coral bleaching indices and thresholds for the Florida Reef Tract, Bahamas, and St. Croix, US Virgin Islands. Mar Pollut Bull 54:1923-1931

> Marsh JAJ (1970) Primary productivity of reef-building calcareous red algae. Ecology 51:255-263

> Meszaros A, Bigger C (1999) Qualitative and quantitative study of wound healing processes in the coelenterate, Plexaurella fusifera: spatial, temporal, and environmental (light attenuation) influences. J Invertebr Pathol 73: 321-331

> Miller J, Waara R, Muller E, Rogers C (2006) Coral bleaching and disease combine to cause extensive mortality on corals reefs in US Virgin Islands. Coral Reefs 25:418

Miller DJ, Hemmrich G, Ball EE, Hayward DC and others (2007) The innate immune repertoire in Cnidaria - ancestral complexity and stochastic gene loss. Genome Biol 8:R59, doi:10.1186/gb-2007-8-4-r59

> Monari M, Matozzo V, Foschi J, Cattani O, Serrazanetti GP, Marin MG (2007) Effects of high temperatures on functional responses of haemocytes in the clam Chamelea gallina. Fish Shellfish Immunol 22:98-114

> Mucklow PT, Vizoso DB, Jensen KH, Refardt D, Ebert D (2004) Variation in phenoloxidase activity and its relation to parasite resistance within and between populations of Daphnia magna. Proc R Soc Lond B Biol Sci 271: 1175-1183

Mullen K, Peters E, Harvell CD (2004) Coral resistance to disease. In: Rosenberg E, Loya Y (eds) Coral health and disease. Springer-Verlag, Berlin

Muller EM, Rogers CS, Spitzack AS, van Woesik R (2008) Bleaching increases likelihood of disease on Acropora palmata (Lamarck) in Hawksnest Bay, St John, US Virgin Islands. Coral Reefs 27:191-195

> Mydlarz LD, Harvell CD (2007) Peroxidase activity and inducibility in the sea fan coral exposed to a fungal pathogen. Comp Biochem Physiol A 146:54-62

> Mydlarz LD, Jones LE, Harvell CD (2006) Innate immunity, environmental drivers and disease ecology of marine and freshwater invertebrates. Annu Rev Ecol Evol Syst 37: 251-288

> Mydlarz LD, Holthouse SF, Peters EC, Harvell CD (2008) Cellular responses in sea fan corals: granular amoebocytes react to pathogen and climate stressors. PLoS ONE 3: e1811, doi:10.1371/journal.pone.0001811

- Nappi AJ, Christensen BM (2005) Melanogenesis and associated cytotoxic reactions: applications to insect innate immunity. Insect Biochem Mol Biol 35:443-459

> Newton K, Peters R, Raftos D (2004) Phenoloxidase and QX disease resistance in Sydney rock oysters (Saccostrea glomerata). Dev Comp Immunol 28:565-569

- Nigam Y, Maudlin I, Welburn S, Ratcliffe NA (1997) Detection of phenoloxidase activity in the hemolymph of tsetse flies, refractory and susceptible to infection with Trypanosoma brucei rhodesiense. J Invertebr Pathol 69:279-281

NOAA Coral Reef Watch (2007) 2005 Caribbean basin 
bleaching event. Available at: http://coralreefwatch.noaa. gov/caribbean 2005

Olano CT, Bigger CH (2000) Phagocytic activities of the gorgonian coral Swiftia exserta. J Invertebr Pathol 76: 176-184

Ordas MC, Ordas A, Beloso C, Figueras A (2000) Immune parameters in carpet shell clams naturally infected with Perkinsus atlanticus. Fish Shellfish Immunol 10:597-609

Oxenford HA, Roach R, Brathwaite A, Nurse L and others (2007) Quantitative observations of a major coral bleaching event in Barbados, southeastern Caribbean. Clim Change 87:435-449

Palmer CV, Mydlarz LD, Willis B (2008) Evidence of an inflammatory-like response in non-normally pigmented tissues of two scleractinian corals. Proc R Soc Lond B Biol Sci doi:10.1098/rspb.2008.0335

Palmer CV, Roth MS, Gates RD (2009) Red fluorescent protein responsible for pigmentation in trematode-infected Porites compressa tissues. Biol Bull (Woods Hole) 216:68-74

Pantos O, Cooney RP, Le Tissier MDA, Barer MR, O'Donnell AG, Bythell JC (2003) The bacterial ecology of a plaguelike disease affecting the Caribbean coral Montastraea annularis. Environ Microbiol 5:370-382

Petes LE, Harvell CD, Peters EC, Webb MAH, Mullen KM (2003) Pathogens compromise reproduction and induce melanization in Caribbean sea fans. Mar Ecol Prog Ser 264:167-171

Ramos R, García E (2007) Induction of mixed-function oxygenase system and antioxidant enzymes in the coral Montastraea faveolata on acute exposure to benzo(a)pyrene. Comp Biochem Physiol C 144:348-355

Ritchie KB (2006) Regulation of microbial populations by coral surface mucus and mucus-associated bacteria. Mar Ecol Prog Ser 322:1-14

Ritchie KB, Smith GW (1995) Preferential carbon utilization by surface bacterial communities from water mass, normal, and white-band diseased Acropora cervicornis. Mol Mar Biol Biotechnol 4:345-352

Schwarz JA, Brokstein PB, Voolstra C, Terry AY, Miller DJ and others (2008) Coral life history and symbiosis: functional genomic resources for two reef building Caribbean

Editorial responsibility: Kiho Kim, Washington, DC, USA corals, Acropora palmata and Montastrea faveolata. BMC Genomics 9:97-105

Siva-Jothy MT (2000) A mechanistic link between parasite resistance and expression of a sexually selected trait in a damselfly. Proc R Soc Lond B Biol Sci 267:2523-2527

Söderhäll K, Cerenius L (1998) Role of the prophenoloxidaseactivating system in invertebrate immunity. Curr Opin Immunol 10:23-28

Söderhäll K, Cerenius L, Johansson MW (1996) The prophenoloxidase activating system in invertebrates. In: Söderhäll K, Iwanaga S, Vasta GR (eds) New directions in invertebrate immunology. SOS Publications, Fair Haven, NJ, p 229-253

Tchernov D, Gorbunov MY, de Vargas C, Yadav SN, Milligan AJ, Haggblom M, Falkowski PG (2004) Membrane lipids of symbiotic algae are diagnostic of sensitivity to thermal bleaching in corals. Proc Natl Acad Sci USA 101: 13531-13535

Thomas MB, Blanford S (2003) Thermal biology in insect-parasite interactions. Trends Ecol Evol 18:344-350

Truscott R, White KN (1990) The influence of metal and temperature stress on the immune system of crabs. Funct Ecol $4: 455-461$

Vargas-Albores F, Hinojosa-Baltazar P, Portillo-Clark G, Magallon-Barajas F (1998) Influence of temperature and salinity on the yellowleg shrimp, Penaeus californiensis Holmes, prophenoloxidase system. Aquac Res 29:549-553

Wang F, Yang H, Gao F, Liu G (2008) Effects of acute temperature or salinity stress on the immune response in sea cucumber, Apostichopus japonicas. Comp Biochem Physiol A 151:491-498

Weis VM (2008) Cellular mechanisms of cnidarian bleaching: stress causes the collapse of symbiosis. J Exp Biol 211: 3059-3066

Weis VM, Davy SK, Hoegh-Guldberg O, Rodriguez-Lanetty M, Pringle JR (2008) Cell biology in model systems as the key to understanding corals. Trends Ecol Evol 23:369-376

Wilkinson C, Souter D (2008) Status of Caribbean coral reefs after bleaching and hurricanes in 2005. Global Coral Reef Monitoring Network, and Reef and Rainforest Research Centre, Townsville

Submitted: January 8, 2009; Accepted: May 12, 2009 Proofs received from author(s): July 7, 2009 